\title{
Introduction of More Editorial Board Members and the Most Frequently Read Articles in 2008
}

\section{Meet JABFM Editorial Board Members Alfred O. Berg and Richard D. Clover}

In an ongoing effort to acquaint our readers with the stellar cast making up the editorial board that advises and serves the fournal of the American Board of Family Medicine ( $7 A B F M)$, we are honored to introduce Alfred Berg and Richard Clover. Similar to those who were featured in our last 2 issues, ${ }^{1,2}$ Drs. Berg and Clover are also members of the Institute of Medicine (IOM) of the National Academy of Sciences. The IOM's mission is to serve as adviser to the nation to improve health. The Institute provides independent, evidence-based, and authoritative information and advice concerning health and science policy to policy-makers, professionals, leaders in every sector of society, and the public at large (http://www.iom.edu/CMS/AboutIOM.aspx).

\section{Alfred O. Berg, MD, MPH}

Dr. Berg is currently Professor and the past chair of Family Medicine at the University of Washington. He received his professional education at Washington University, St. Louis (MD), the University of Missouri, Columbia, and the University of Washington, Seattle (MPH); he completed residencies in family medicine and in general preventive medicine and public health. Dr. Berg was elected to the IOM of the National Academy of Sciences in 1996. In 2004, he received the Thomas W. Johnson Award for career contributions to family medicine education from the American Academy of Family Physicians, and in 2008, he received the F. Marian Bishop Leadership Award from the Society of Teachers of Family Medicine Foundation recognizing his contribution to enhancing the academic credibility of family medicine.

Dr. Berg has served on many national expert panels using evidence-based methods to develop clinical guidelines, including chairmanship of the United States Preventive Services Task Force, co-

Conflict of interest: The authors are editors of the $7 A B F M$.

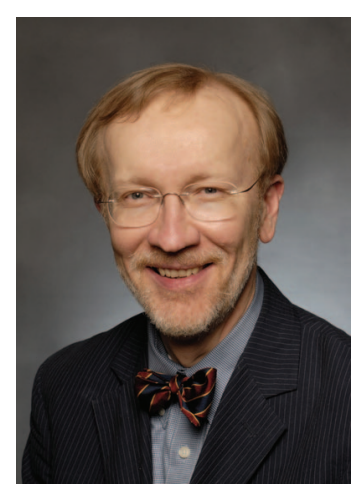

Alfred 0. Berg, MD, MPH

chair of the otitis media panel convened by the Agency for Health Care Policy and Research, chair of the Centers for Disease Control (CDC) and Prevention Sexually Transmitted Diseases Treatment Guidelines panel, member of the American Medical Association/CDC panel producing Guidelines for Adolescent Preventive Services, member of the IOM's Immunization Safety Review Committee, and chair of the IOM's Committee on Treatment of Post Traumatic Stress Disorder. He currently chairs the CDC panel on Evaluation of Genomic Applications in Practice and Prevention and the National Institutes of Health State-of-the Science Conference on Family History in Primary Care.

\section{Richard D. Clover, MD}

Richard D. Clover, MD, is founding Dean of the School of Public Health and Information Sciences at the University of Louisville, Kentucky. He also serves as Co-Director of the Center for Health Hazards Preparedness and Associate Vice President for Health Informatics at the University of Louisville Health Sciences Center. Dr. Clover earned his medical degree from the University of Oklahoma College of Medicine in Oklahoma City, where he completed his residency at the Enid Family Medicine Clinic. He completed a fellowship at the University of Oklahoma, during which he developed his interest in infectious diseases. Dr. Clover's re- 


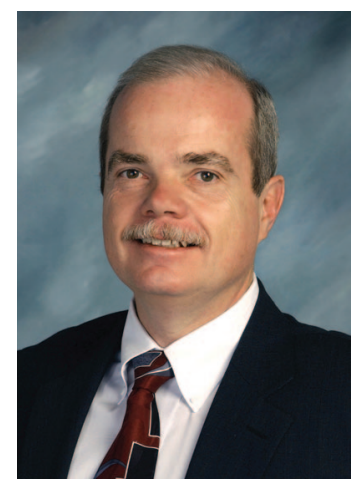

Richard D. Clover, MD

search interests include vaccine-preventable diseases, health policy, and health informatics. He has published in numerous peer-reviewed journals including the American Fournal of Public Health, the New England Fournal of Medicine, Pediatrics, the Fournal of Infectious Diseases, American Family Physician, and the Fournal of Family Practice. He also serves on the editorial board of the National Network for Immunization Information.

Dr. Clover is a member of the US Department of Health and Human Services' National Vaccine Advisory Committee, where he serves as the chair of the Adult Immunization Working Group. He is a past member of the Advisory Committee on Immunization Practices, Centers for Disease Control and Prevention, and a member of the American Board of Medicine, Board of Directors, and past chair of the American Academy of Family Physicians Commission on Clinical Policies and Research.

\section{Top 20JABFM Online Articles}

Table 1 shows the top 20 most frequently read articles in the $7 A B F M$ for January 2008 through January 2009. Specific articles continue to be relevant to readers, with 13 of the 20 articles appearing on the 2007 top 20 list. $^{3}$ Fourteen of the articles were published in 2005 or earlier, showing that older articles maintain their popularity with FABFM readers. The 2 newest articles included on the list discuss abuse of medications ${ }^{4}$ and postpartum depression screening ${ }^{5}$; both are problems frequently seen in family medicine.

\section{Content Usage}

Figure 1 illustrates both the number of total access events and full-text HTML and PDF accesses for 2008; a new issue is published bimonthly and is also noted. With an average of 167,500 monthly and a total of more than 2 million yearly content usage requests, 2008 proved to be the busiest year for online usage activity in $7 A B F M$ history. Usage activity was up $30 \%$ in 2008 when compared with 2007 content usage requests. Full-text HTML articles were the most accessed in 2008 with an average of 68,900 monthly requests followed by abstracts with 35,600 average monthly requests and PDF articles with 35,200 average monthly requests. We thank you, our reading community, for your continued support of the $7 A B F M$.

\section{JABFM is Now on Facebook}

The $7 A B F M$ is always looking for ways to connect with its reading community and we now have a page on Facebook for members to join and meet other readers. The page will also be used to promote special issues and call for papers. To find the $7 A B F M$, simply type $7 A B F M$ in the search bar at the top of the Facebook page. After clicking on our page, you can become a fan of the $7 A B F M$. You must have a Facebook account (www.facebook. com) to view the $7 A B F M$ page.

Phillip Lupo, MLIS Anne Victoria Neale, PhD, MPH Marjorie A. Bowman, MD, MPA 
1. Margaret M. Eberl, Chester H. Fox, Stephen B. Edge, Cathleen A. Carter, Martin C. Mahoney BI-RADS Classification for Management of Abnormal Mammograms ${ }^{6 \neq}$

Article link: http://www.jabfm.org/cgi/content/full/19/2/161

2. John W. Ely, Jerome A. Osheroff, M. Lee Chambliss, Mark H. Ebell Approach to Leg Edema of Unclear Etiology ${ }^{7 \ddagger}$

Article link: http://www.jabfm.org/cgi/content/full/19/2/148

3. John Abramson, Barbara Starfield

The Effect of Conflict of Interest on Biomedical Research and Clinical Practice Guidelines: Can We Trust the Evidence in Evidence-Based Medicine? ${ }^{8}$

Article link: http://www.jabfm.org/cgi/content/full/18/5/414

4. John W. Ely, Colleen M. Kennedy, Elizabeth C. Clark, Noelle C. Bowdler

Abnormal Uterine Bleeding: A Management Algorithm ${ }^{\text {9* }}$

Article link: http://www.jabfm.org/cgi/content/full/19/6/590

5. Anne Victoria Neale, Kendra L. Schwartz, Marjorie A. Bowman

Conflict of Interest: Can We Minimize Its Influence in the Biomedical Literature? ${ }^{10}$

Article link: http://www.jabfm.org/cgi/content/full/18/5/411

6. Anthony A. Mork, Scott M. W. Haufe, William B. Yancey

Sometimes (What Seems to Be) A Heart Attack Is (Really) A Pain In The Neck ${ }^{11 \neq}$

Article link: http://www.jabfm.org/cgi/content/full/17/1/74

7. Saili Desai, Diana Aldea, Elisabeth Daneels, Manal Soliman, Amy S. Braksmajer, Colin P. Kopes-Kerr Chronic Addiction to Dextromethorphan Cough Syrup: A Case Report ${ }^{12 \ddagger}$

Article link: http://www.jabfm.org/cgi/content/full/19/3/320

8. Celia M. Ross

Fish Oil versus Cod Liver Oil: Is Vitamin D a Reason to Go Back to the Future ${ }^{13}$

Article link: http://www.jabfm.org/cgi/content/full/18/5/445-b

9. Liana Gold, Helena Igra

Levofloxacin-Induced Tendon Rupture: A Case Report and Review of the Literature ${ }^{14}$

Article link: http://www.jabfm.org/cgi/content/full/16/5/458

10. James E. Lessenger, Steven D. Feinberg

Abuse of Prescription and Over-the-Counter Medications ${ }^{4}$

Article link: http://www.jabfm.org/cgi/content/full/21/1/45

11. Alan B. Douglass, Edward T. Bope

Evaluation and Treatment of Posterior Neck Pain in Family Practice ${ }^{15 \ddagger}$

Article link: http://www.jabfm.org/cgi/content/full/17/suppl_1/S13

12. John A. Astin, Shauna L. Shapiro, David M. Eisenberg, Kelly L. Forys

Mind-Body Medicine: State of the Science, Implications for Practice ${ }^{16 \neq}$

Article link: http://www.jabfm.org/cgi/content/full/16/2/131

13. Tamara J. Dominguez

It's Not a Spider Bite, It's Community-Acquired Methicillin-Resistant Staphylococcus aureus ${ }^{17 \ddagger}$

Article link: http://www.jabfm.org/cgi/content/full/17/3/220

14. Andre F. Lijoi, Joanna Brady

Vasa Previa Diagnosis and Management ${ }^{18 \ddagger}$

Article link: http://www.jabfm.org/cgi/content/full/16/6/543

15. Jonathan A. Drezner, Brian J. Sennett

Subacromial/Subdeltoid Septic Bursitis Associated with Isotretinoin Therapy and Corticosteroid Injection ${ }^{19}$

Article link: http://www.jabfm.org/cgi/content/full/17/4/299

16. Erika N. Ringdahl, Susan L. Pereira, John E. Delzell

Treatment of Primary Insomnia ${ }^{20 \ddagger}$

Article link: http://www.jabfm.org/cgi/content/full/17/3/212

17. Dwenda K. Gjerdingen, Barbara P. Yawn

Postpartum Depression Screening: Importance, Methods, Barriers, and Recommendations for Practice ${ }^{5}$ Article link: http://www.jabfm.org/cgi/content/full/20/3/280

18. Lee T. Dresang

A Molar Pregnancy Detected by Following B-Human Chorionic Gonadotropin Levels after a First Trimester Loss ${ }^{21 \neq}$ Article link: http://www.jabfm.org/cgi/content/full/18/6/570

19. Robert $\mathrm{Oh}$

Practical Applications of Fish Oil ( $\Omega-3$ Fatty Acids) in Primary Care Ca $^{22 \ddagger}$

Article link: http://www.jabfm.org/cgi/content/full/18/1/28 
Table 1. Continued

20. Dwenda Gjerdingen

The Effectiveness of Various Postpartum Depression Treatments and the Impact of Antidepressant Drugs on Nursing Infants ${ }^{23 \neq}$

Article link: http://www.jabfm.org/cgi/content/full/16/5/372

*The most-read rankings are recalculated at the beginning of each month. Rankings are based on hits received by articles archived on the $7 A B F M$ website only.

${ }^{\dagger}$ Data source: "The 20 Most Frequently Read Articles" for the $7 A B F M$, January 2008 through January 2009, HighWire Press; updated monthly, last on February 11, 2009 (accessed March 4, 2009).

${ }^{\ddagger}$ This article was also on the 2007 list of "The 20 Most Read Articles" $\left(^{3}\right)$.

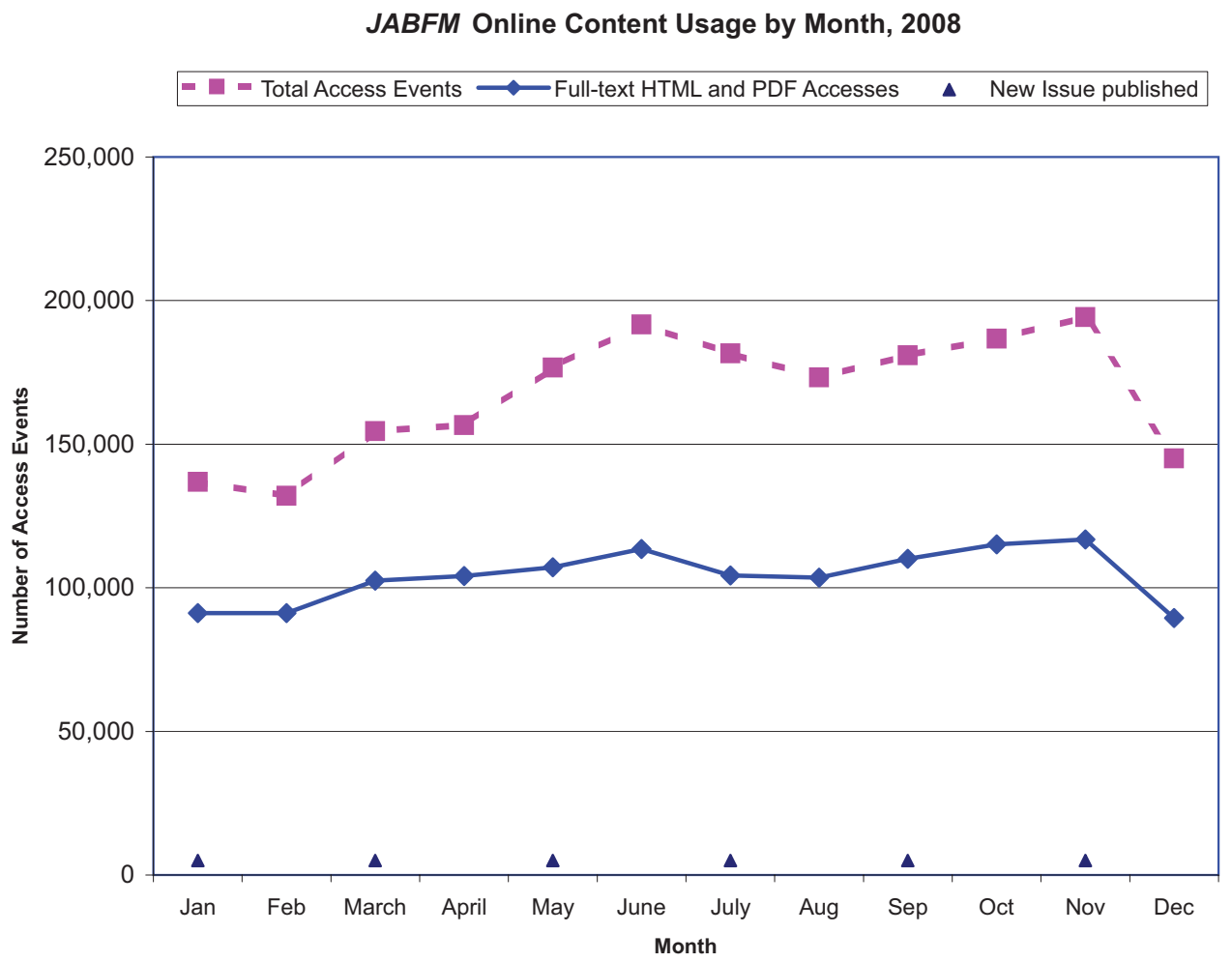

Figure 1. Data source: "Year-to-Date Usage Summary" for the JABFM, HighWire Press, produced February 11, 2009 (accessed March 4, 2009). 


\section{References}

1. Neale AV, Bowman MA, Lupo P. $7 A B F M$ editorial board member's election to the Institute of Medicine and new journal alerts and features. J Am Board Fam Med 2009;22(1):4-5.

2. Neale AV, Bowman MA, Lupo P. Introduction of more editorial board members and Fournal of the American Board of Family Medicine's position on the National Institutes of Health Public Access Policy. J Am Board Fam Med 2009;22(2):107-9.

3. Bowman MA, Neale AV, Lupo P. Inside the March/ April 2008 issue and the most frequently-read articles in 2007. J Am Board Fam Med 2008;21(2):8790 .

4. Lessenger JE, Feinberg SD. Abuse of prescription and over-the-counter medications. J Am Board Fam Med 2008;21(1):45-54.

5. Gjerdingen DK, Yawn BP. Postpartum depression screening: importance, methods, barriers, and recommendations for practice. J Am Board Fam Med 2007;20(3):280-8.

6. Eberl MM, Fox CH, Edge SB, Carter CA, Mahoney MC. BI-RADS classification for management of abnormal mammograms. J Am Board Fam Med 2006; 19(2):161-4.

7. Ely JW, Osheroff JA, Chambliss ML, Ebell MH. Approach to leg edema of unclear etiology. J Am Board Fam Med 2006;19(2):148-60.

8. Abramson J, Starfield B. The effect of conflict of interest on biomedical research and clinical practice guidelines: can we trust the evidence in evidencebased medicine? J Am Board Fam Med 2005;18(5): 414-8.

9. Ely JW, Kennedy CM, Clark EC, Bowdler NC. Abnormal uterine bleeding: a management algorithm. J Am Board Fam Med 2006;19(6):590-602.

10. Neale AV, Schwartz KL, Bowman MA. Conflict of interest: can we minimize its influence in the biomedical literature? J Am Board Fam Pract 2005; 18(5):411-3.

11. Mork AA, Haufe SMW, Yancey WB. Sometimes (what seems to be) a heart attack is (really) a pain in the neck. J Am Board Fam Pract 2004;17(1):74-7.

12. Desai S, Aldea D, Daneels E, Soliman M, Braksmajer AS, Kopes-Kerr CP. Chronic addiction to dextromethorphan cough syrup: a case report. J Am Board Fam Med 2006;19(3):320-3.

13. Ross CM. Fish oil versus cod liver oil: is Vitamin D a reason to go back to the future. J Am Board Fam Pract 2005;18(5):445-6.

14. Gold L, Igra H. Levofloxacin-induced tendon rupture: a case report and review of the literature. J Am Board Fam Pract 2003;16(5):458-60.

15. Douglass AB, Bope ET. Evaluation and treatment of posterior neck pain in family practice. J Am Board Fam Pract 2004;17(S1):13-22.

16. Astin JA, Shapiro SL, Eisenberg DM, Forys KL. Mind-body medicine: state of the science, implications for practice. J Am Board Fam Pract 2003;16(2): 131-47.

17. Dominguez TJ. It's not a spider bite, it's communityacquired methicillin-resistant staphylococcus aureus. J Am Board Fam Pract 2004;17(3):220-6.

18. Lijoi AF, Brady J. Vasa previa diagnosis and management. J Am Board Fam Pract 2003;16(6):543-8.

19. Drezner JA, Sennett BJ. Subacromial/subdeltoid septic bursitis associated with isotretinoin therapy and corticosteroid injection. J Am Board Fam Pract 2004;17(4):299-302.

20. Ringdahl EN, Pereira SL, Delzell JE. Treatment of primary insomnia. J Am Board Fam Pract 2004; 17(3):212-9.

21. Dresang LT. A molar pregnancy detected by following $\beta$-human chorionic gonadotropin levels after a first trimester loss. J Am Board Fam Pract 2005; 18(6):570-3.

22. Oh R. Practical applications of fish oil (Ü-3 fatty acids) in primary care. J Am Board Fam Pract 2005; 18(1):28-36.

23. Gjerdingen D. The effectiveness of various postpartum depression treatments and the impact of antidepressant drugs on nursing infants. J Am Board Fam Pract 2003;16(5):372-82. 